\title{
The Role of Environmental Heterogeneity in Maintenance of Anuran Amphibian Diversity of the Brazilian Mesophytic Semideciduous Forest
}

\author{
Tiago Gomes dos Santos 1,2 , \\ Tiago da Silveira Vasconcelos ${ }^{1}$ and Célio Fernando Baptista Haddad ${ }^{1}$ \\ ${ }^{1}$ Universidade Estadual Paulista, \\ ${ }^{2}$ Universidade Federal do Pampa, \\ Brazil
}

\section{Introduction}

Since the 1950s, most ecologists have assumed that animal communities are not simply random assemblages of species (Wells, 2007). Therefore, deterministic factors were pointed out as being responsible for the variation in species diversity and composition along environmental and/or spatio-temporal gradients (Chase \& Leibold, 2003). However, according to the recent Hubbell's Neutral Theory, the structure of assemblages (such as diversity and species composition) results from stochastic processes (i.e. ecological drift) that are not influenced by species traits and/or environmental conditions (see details in Tilman, 2004 and Chase, 2007). Therefore the Neutral Theory predicts that species abundance results solely from structured random walks, leaving unexplained the correlations between species traits and their abundances within habitats and/or along environmental gradients (see references in Tilman, 2004).

Some studies highlighted that Neotropical assemblages show little or no structure (Eterovick \& Barros, 2003, Afonso \& Eterovick, 2007 for anurans and França \& Araújo, 2007 for snakes), corroborating the Neutral Theory. On the other hand, partitioning of resources has been historically stressed in terms of both space and time for anuran assemblages (Crump, 1971), where a temporal axis has been considered the first dimension partitioned in the larval phase, and space in adult phase (Toft, 1985). Several studies showed that similar habitats within relatively close distance often have slightly different amphibian assemblages since some species live in a variety of habitats, while others can have more specialized habitat requirements (Snodgrass et al., 2000; Wells, 2007). Therefore, most anuran assemblages appear to be structured since differences in environmental conditions from site to site have explained differences in assemblage features such as richness and abundance of species (Toft, 1982). In addition, other factors such as biological interactions (e.g., predation and competition) and phylogenetic constraints are also considered important to explain structural patterns of assemblages (Zimmerman \& Simberlof, 1996; Eterovick \& Sazima, 2000; Eason Jr. \& Fauth, 2001; Werner et al., 2007). 
According to Paton \& Crouch (2002) and Bosch \& Martínez-Solano (2003), local studies on breeding site preferences of amphibians can provide more accurate information for management purposes than studies on a wider scale, which can be affected by regional variations. In fact, spatial segregation in breeding site occupancy has been recorded for adult and/or larval assemblages of anurans on a local scale (Collins \& Wilbur, 1979; Gascon, 1991; Santos et al., 2007; Both et al., 2009) but unfortunately, few studies have applied specific approaches to confirm assemblage structures (see Both et al., 2010; Vasconcelos et al., 2011 for recent examples). Thus, studies on the spatial pattern of assemblages are urgently required to delineate conservation strategies for anurans in ecosystems under strong anthropogenic pressure such as the Mesophytic Semideciduous Forest (MSF), the most fragmented and threatened ecosystem of the Brazilian Atlantic Domain (Viana \& Tabanez, 1996). This kind of forest was almost totally devastated because of their soil fertility, smooth relief and high availability of valuable hardwood and because of unscrupulous political interests (Murphy \& Lugo, 1986; Prado \& Gibbs, 1993; Dean, 1998). Besides, the Semideciduous Forests have been historically neglected as areas for conservation unit creation because of their low level of endemism when compared with the humid forests (Jansen, 1997; Prado, 2000; Pennington et al., 2006).

In the present study, we employed tests of null hypotheses to assess whether patterns of spatial distribution of anuran assemblages differ from a random distribution among aquatic breeding sites monitored at Morro do Diabo State Park (MDSP), one of the four largest remnants of MSF in Brazil (Durigan \& Franco, 2006). We also verified the existence of indicator anuran species of environmental heterogeneity on a local scale.

\section{Material and methods}

\subsection{Study area and sampling procedures}

We carried out this study in MDSP, a remnant of seasonally dry tropical forest with approximately 33,845 ha in area, located in southeastern Brazil $\left(22^{\circ} 27^{\prime}--22^{\circ} 40^{\prime} \mathrm{S}, 52^{\circ} 10^{\prime}--\right.$ $52^{\circ} 22^{\prime} \mathrm{W}$ ), where the altitude ranges from 260 to $599.50 \mathrm{~m}$ a.s.l.) (Fig. 1). MDSP is covered by a mosaic of Mesophytic Semideciduous Forest in different stages of regeneration, some small patches of Cerrado sensu stricto (savanna-like vegetation), and transitional forests (Durigan \& Franco, 2006). The climate is characterized as subtropical with dry winters and wet summers (Cwa type of Köppen's classification) (Leite, 1998), and historical records indicate a mean annual temperature of $22^{\circ} \mathrm{C}$ and annual rainfall ranging from 1,100 to 1,300 $\mathrm{mm}$ (Faria, 2006).

We monthly monitored (from September 2005 to March 2007) six anuran breeding sites in MDSP: two permanent streams (PS1 and PS2; sections of $500 \mathrm{~m}$ in length), two permanent dams (PD1 and PD2), and two temporary ponds (TP1 and TP2; see a complete characterization in Table 1). Physicochemical water measurements were collected and based on a mean of three samples, using a Hach 2100P Turbidimeter (for turbidity) and an YSI 556 Handheld Multiparameter (for the remaining variables).

Permanent dams were located within the borders of forests and presented great depth, low canopy cover, and a bed composed of clay and organic deposits. Dam waters showed low electric conductivity, intermediate oxygenation, and high richness in potential aquatic predators (insects, crustaceans, and fish) (Table 1). 


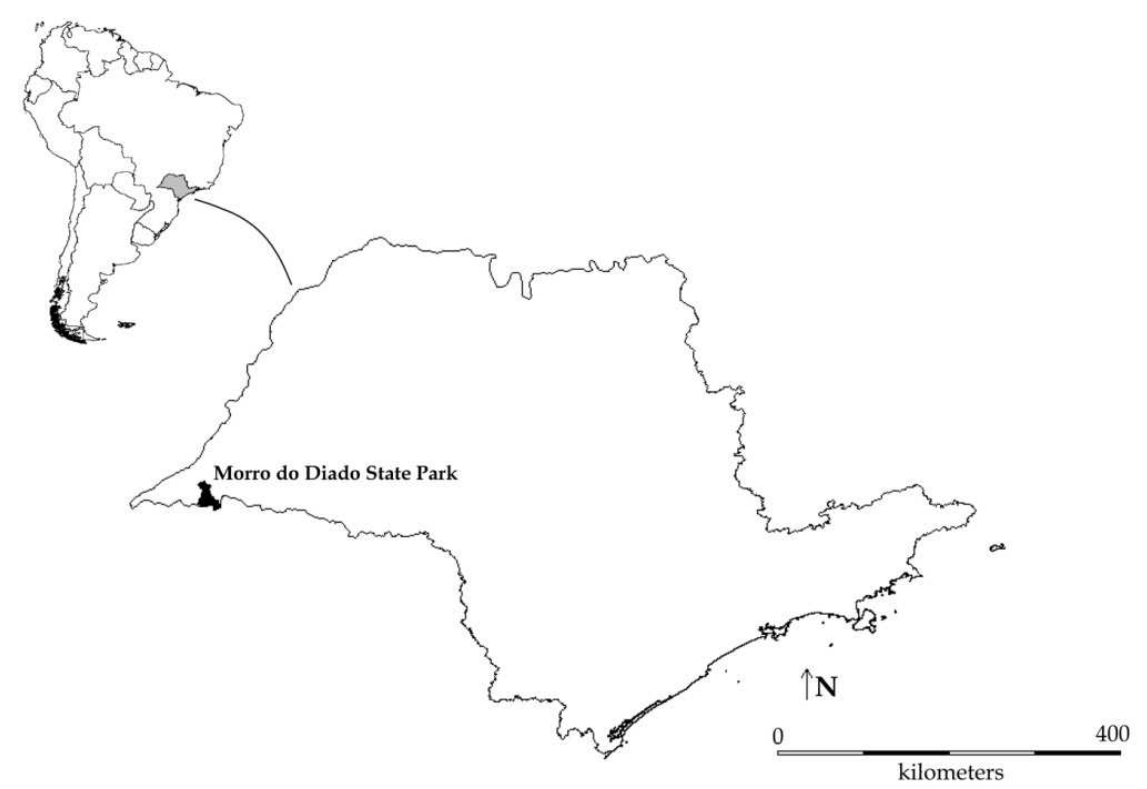

Fig. 1. Geographical localization of the studied area (Morro do Diabo State Park: MDSP), located in the westernmost region of the state of São Paulo, southeastern Brazil.

Permanent streams were located inside the forests and presented a bed mainly composed of sand (PS2) and gravel (PS1), and backwaters with deposits of mud and organic matter. Stream waters were well oxygenated with intermediate conductivity, had a lower temperature than permanent dams and temporary ponds, and high richness of potential aquatic predators (Table 1).

Temporary ponds were shallow and presented a bed covered by leaf litter and other detritus of terrestrial vegetation (such as decaying grasses in TP2) that grows in dry pond basins. Temporary pond water presented high conductivity, low dissolved oxygen, and low richness in potential aquatic predators (Table 1). In addition, temporary waters presented brownish coloration and high salinity, probably due to humic substances and evaporation respectively (Williams, 2006). However, the two temporary ponds differed regarding their canopy cover, since water surface of TP1 was covered by trees whereas TP2 was scarcely shadowed.

We recorded the monthly abundance of anuran species in each breeding site by performing the "surveys at breeding sites" methodology (Scott \& Woodward, 1994) during the nocturnal period (from sunset to midnight, when most species had already reduced their calling activities). The search for anurans was made along the perimeters of breeding sites, by recording males engaged in calling activities. Habitat inspections were carried out using artificial light (head lamps), a methodology widely performed and recommend in protocols of inventory and monitoring of amphibians (Heyer et al., 1994), since males of anurans call even if under artificial light. The amount of time spent in each breeding site varied according to its size and complexity (Scott \& Woodward, 1994). Additional information regarding MDSP characterization and sampling schedule is available in Santos et al. (2009) and Vasconcelos et al. (2009). 


\begin{tabular}{|c|c|c|c|c|c|c|}
\hline \multirow{2}{*}{$\begin{array}{l}\text { Environmental } \\
\text { describers }\end{array}$} & \multicolumn{6}{|c|}{ Breeding sites } \\
\hline & PD1 & PD2 & PS1 & PS2 & TP1 & TP2 \\
\hline $\begin{array}{l}\text { Geographic } \\
\text { coordinates }\end{array}$ & $\begin{array}{c}22^{\circ} 27^{\prime} 03.7^{\prime \prime} S \\
52^{\circ} 20^{\prime} 43.3^{\prime \prime} \\
\text { W }\end{array}$ & $\begin{array}{c}22^{\circ} 37^{\prime} 00.4^{\prime \prime} S \\
52^{\circ} 10^{\prime} 09.5^{\prime \prime} \\
W\end{array}$ & $\begin{array}{c}22^{\circ} 36^{\prime} 16.2^{\prime \prime} S \\
52^{\circ} 18^{\prime} 00.8^{\prime \prime} \\
W\end{array}$ & $\begin{array}{c}22^{\circ} 28^{\prime} 30.8^{\prime \prime} S \\
52^{\circ} 20^{\prime} 30.9^{\prime \prime} \\
\text { W }\end{array}$ & $\begin{array}{c}22^{\circ} 37^{\prime} 10.5^{\prime \prime} S \\
52^{\circ} 09^{\prime} 55.8^{\prime \prime} \\
W\end{array}$ & $\begin{array}{c}22^{\circ} 37^{\prime} 07.8^{\prime \prime} \mathrm{S} \\
52^{\circ} 10^{\prime} 01.9^{\prime \prime} \\
\text { W }\end{array}$ \\
\hline \multicolumn{7}{|l|}{ Water features } \\
\hline $\begin{array}{l}\text { Electric } \\
\text { conductivity } \\
(\mu \mathrm{S} / \mathrm{cm})\end{array}$ & 18.33 & 14.67 & 24.33 & 21 & 49.33 & 33.67 \\
\hline $\begin{array}{l}\text { Dissolved } \mathrm{O}_{2} \\
{[\mathrm{mg} / \mathrm{L}(\%)]}\end{array}$ & $5.74(72.3)$ & 3.39 (41.1) & 7.88 (90.4) & $8.04(92.8)$ & $1.24(15.43)$ & 1.25 (15.3) \\
\hline $\mathrm{pH}$ & 5.8 & 4.67 & 6.61 & 5.68 & 5.8 & 5.52 \\
\hline Salinity (ppt) & 0.01 & 0.01 & 0.01 & 0.01 & 0.02 & 0.01 \\
\hline $\begin{array}{l}\text { Temperature } \\
\left({ }^{\circ} \mathrm{C}\right)\end{array}$ & 27.08 & 25.12 & 22.1 & 22.51 & 26.52 & 25.27 \\
\hline $\begin{array}{l}\text { Turbidity } \\
\text { (ntu) }\end{array}$ & 5.61 & 26.57 & 18.03 & 5.12 & 10.75 & 46.74 \\
\hline Movement & io & $\mathrm{s}$ & $\mathrm{r}$ & $\mathrm{r}$ & s & s \\
\hline \multicolumn{7}{|l|}{ Size (m) } \\
\hline Length & 200 & 25 & 500 & 500 & 70 & 26 \\
\hline Width & 50 & 5 & 2.13 & 2.7 & 50 & 27 \\
\hline Depth & $>2$ & $>2$ & 0.14 & 0.26 & 0.4 & 0.48 \\
\hline $\begin{array}{l}\text { Hydroperiod } \\
\text { (months) }\end{array}$ & 18 & 18 & 18 & 18 & 10 & 8 \\
\hline Origin & $\mathrm{m}$ & $\mathrm{m}$ & $\mathrm{n}$ & $\mathrm{n}$ & $\mathrm{n}$ & $\mathrm{n}$ \\
\hline $\begin{array}{l}\text { Canopy cover } \\
(\%)\end{array}$ & $<5$ & $<5$ & 80 & 70 & 90 & $<5$ \\
\hline Edge type & $\mathrm{fl}$, st & st & $\mathrm{fl}$, st & $\mathrm{fl}$, st & $\mathrm{fl}$ & $\mathrm{fl}$, st \\
\hline $\begin{array}{l}\text { Bed substrate } \\
\text { type }\end{array}$ & yc, om & yc, om & $\begin{array}{l}\text { sa, om, co, } \\
\text { gr }\end{array}$ & sa, om, af & om, yc & om, yc \\
\hline \multicolumn{7}{|l|}{$\begin{array}{l}\text { Vegetation } \\
\text { type }\end{array}$} \\
\hline Aquatic & he & he & he & he & he, sh, ar & he, sh \\
\hline Edges & he, sh, ar & he, sh, ar & he, sh, ar & he, sh, ar & he, sh, ar & he, sh, ar \\
\hline Matrix & $\mathrm{fm}, \mathrm{oa}$ & $o a, r f, f p$ & $\mathrm{mf}$ & $\mathrm{fm}$ & $\mathrm{oa}, \mathrm{rf}$ & oa, rf \\
\hline \multicolumn{7}{|l|}{$\begin{array}{l}\text { Richness of } \\
\text { aquatic } \\
\text { predators }\end{array}$} \\
\hline Fish & 4 & 3 & 4 & 3 & 1 & 1 \\
\hline $\begin{array}{l}\text { Insects and } \\
\text { crustaceans }\end{array}$ & 10 & 6 & 12 & 12 & 5 & 4 \\
\hline
\end{tabular}

Table 1. Localization and environmental characterization of six breeding sites monitored in Morro do Diabo State Park, São Paulo state, southeastern Brazil. Breeding sites: Permanent dams (PD), permanent streams (PS), and temporary ponds (TP); Water movement: running 
(r), inlet and outlet flow (io), and standing (s); Hydroperiod: number of months with water from September 2005 to March 2007; Origin: man-made (m), and natural (n); Edge type: flat (fl), and steep (st); Bed substrate type: sand (sa), yellow clay (yc), gravel (gr), arenilitic flagstone (af), accumulation of organic matter and mud (om), and cobble (co); Vegetation type: herbaceous (he), shrubby (sh), and arboreal (ar); Matrix vegetation type: disturbed open area (oa), Forest of Myrtaceae (fm), Forest of Pinus (fp), regeneration of Mesophytic Semideciduous Forest (rf), mature Mesophytic Semideciduous Forest (mf); Aquatic predator richness: numbers of families of insects and crustaceans, and number of species of fish collected with dip nets through monthly sampling.

\subsection{Statistical analyses}

We carried out an environmental representation of the monitored breeding sites in MDSP by calculating the Euclidean Distance index (Krebs, 1999) on abiotic and biotic quantitative measurements (i.e. physicochemical water features, size, canopy cover, and richness in potential aquatic predators). We based Euclidean Distances on transformed (square root) and normalized (by standard deviation) environmental variables, due to deviations of normality of original data and no comparable measurement scales (Clarke \& Gorley, 2006). In addition, we tested the existence of spatial patterns in the distribution of anuran assemblages among the six breeding sites monitored by computing similarity analysis (Bray-Curtis index) (Krebs, 1999). We based the similarity matrix on the total abundance of anuran species in each breeding site. Abundance of each species in each breeding site was considered as the highest number of calling males recorded during the monitored period. We adopted this procedure to avoid overestimation of species due to recounting individuals in a serial sampling schedule (Gottsberger \& Gruber, 2004; Vasconcelos \& Rossa-Feres, 2005; Santos et al., 2007).

We represented dissimilarity and similarity matrices by cluster analysis (UPGMA) (Krebs, 1999), and accessed statistical significance of genuine clusters performing the SIMPROF similarity profile test (Clarke \& Gorley, 2006). SIMPROF is a series of permutation tests of the null hypothesis that assumes that the samples are a priori unstructured (i.e. that the breeding sites are unstructured regarding environmental characteristics and/or anuran assemblages). This test is based on an expected profile shape of similarity/dissimilarity obtained by permuting the entries for each variable 1,000 times (i.e. species and/or environmental variables) across that subset of samples; this produces a null condition in which samples have no group structure. The 1,000 permuted values are averaged to produce a mean profile which is statically compared (999 times) with the real similarity profile by absolute distances (Phi) (Clarke \& Gorley, 2006). According to Clarke \& Gorley (2006), whether environmental variables are responsible for structuring assemblages, it is expected that a plot, based on environmental information, groups the breeding sites in the same way as for a species composition plot. Therefore, we looked for concordance among cluster plots of environmental characteristics and anuran assemblages, in order to explain the spatial patterns of breeding sites used by anurans in MDSP.

We also computed Principal Components Analysis (PCA) (Legendre \& Legendre, 1998) to represent together the monthly samples of breeding sites and the species. The purpose of this analysis was to capture as much as possible the variability of the original dataset in a 
low-dimensional solution, represented by orthogonal axes. Thus, most of the variance is accounted for on the first two or three axes (Clarke \& Warwick, 2001; Manly, 2008). We based PCA on a variance/covariance matrix, since we measured all variables in the same unit (i.e. abundance of anurans). Because our data set was composed of temporally serial samples (sensu Legendre \& Legendre, 1998) and because we were more interested in spatial rather than temporal structures, we used a covariable matrix in PCA, representing time of sampling (i.e. sampling months as dummy variables) to minimize temporal effects in PCA solution.

Finally, we performed the Indicator Species Analysis (ISA) (Dufrêne \& Legendre, 1997) to test for the existence of indicator species of environmental heterogeneity. This method is based on a data matrix where there are data groups (a priori established) that can be indicated by some species. According to McCune \& Mefford (1999), each species receives an indicator value (IV) of each group, which varies from zero (no indication) to 100 (perfect indication). The null hypothesis in ISA considers that the maximum IV is not greater than that expected by chance. The indicator value is calculated using relative abundance and relative frequency of species across the sample units (considered herein as the monthly records of species abundance in each breeding site). Thus, a good indicator species of a determined group must be frequent and abundant across the samples in this group (Dufrêne \& Legendre, 1997). Established groups for ISA were considered based on the clusters indicated by SIMPROF and PCA analyses. Statistical significances of the maximum value indicated for each group were performed using the Monte Carlo permutation test (Manly, 1998) (5,000 times). We based all analyses on log-transformed $(\log x+1)$ abundance of anuran species in order to down-weight the contributions of quantitatively dominant species in the similarity analysis, and to linearize relationships in PCA analysis. SIMPROF and ISA analyses were performed using Primer-E 6.1 (Clarke \& Gorley, 2006) and PC-ORD 4.0 (McCune \& Mefford, 1999) software respectively. PCA was performed using CANOCO 4.0 for Windows software (ter Braak \& Smilauer, 1998).

\section{Results}

We recorded a total of 23 anuran species in the six monitored breeding sites in MDSP and the number of anuran species in the breeding sites ranged from three (PS2) to 17 species (TP1) (Table 2). Anuran abundance ranged from 22 (PS2) to 316 individuals (TP1) (Table 2).

The SIMPROF similarity profile test showed three consistent groups of breeding sites in relation to environmental characteristics: permanent dams, permanent streams, and temporary ponds (Fig. 2A). The first node separated temporary ponds from permanent dams and permanent streams (Fig. 2A). The second node separated permanent streams from permanent dams (Fig. 2A). In addition, the SIMPROF test also showed that anuran species differed from a spatial distribution expected by chance and clustered three consistent groups of breeding sites in MDSP (Fig. 2B). These groups correspond to the same groups previously evidenced by the environmental features (Fig. 2A). The first node separated lotic (permanent streams) from lentic environments (permanent dams and temporary ponds), whilst the second node separated lentic environments in permanent dams and temporary ponds (Fig. 2B). The multivariate structure within the genuine clusters did not differ statistically (Fig. 2). 


\begin{tabular}{lcccccc}
\hline Species & PD1 & PD2 & PS1 & PS2 & TP1 & TP2 \\
\hline Chiasmocleis albopunctata & 0 & 0 & 0 & 0 & 7 & 15 \\
Dendropsophus minutus & 0 & 0 & 0 & 0 & 5 & 1 \\
Dendropsophus nanus & 50 & 20 & 0 & 0 & 45 & 25 \\
Elaschistocleis bicolor & 0 & 0 & 0 & 0 & 30 & 25 \\
Hypsiboas albopunctatus & 1 & 5 & 5 & 18 & 0 & 0 \\
Hypsiboas lundii & 0 & 0 & 0 & 1 & 0 & 0 \\
Hypsiboas punctatus & 0 & 12 & 0 & 0 & 0 & 0 \\
Hypsiboas raniceps & 6 & 0 & 0 & 0 & 20 & 8 \\
Leptodactylus chaquensis & 0 & 0 & 0 & 0 & 7 & 1 \\
Leptodactylus fuscus & 0 & 0 & 0 & 0 & 2 & 4 \\
Leptodactylus labyrinthicus & 0 & 0 & 0 & 0 & 1 & 0 \\
Leptodactylus mystaceus & 0 & 0 & 3 & 0 & 1 & 0 \\
Leptodactylus mystacinus & 0 & 0 & 0 & 0 & 20 & 8 \\
Leptodactylus podicipinus & 10 & 2 & 6 & 3 & 100 & 30 \\
Physalaemus cuvieri & 8 & 0 & 7 & 0 & 32 & 15 \\
Pseudis platensis & 0 & 0 & 0 & 0 & 1 & 0 \\
Rhinella ornata & 0 & 0 & 13 & 0 & 0 & 0 \\
Rhinella schneideri & 3 & 0 & 0 & 0 & 0 & 0 \\
Scinax berthae & 0 & 5 & 0 & 0 & 17 & 11 \\
Scinax fuscomarginatus & 60 & 12 & 0 & 0 & 0 & 0 \\
Scinax fuscovarius & 0 & 0 & 0 & 0 & 8 & 3 \\
Scinax similis & 0 & 0 & 0 & 0 & 2 & 30 \\
Trachycephalus typhonius & 0 & 0 & 1 & 0 & 18 & 5 \\
\hline Species abundance & 138 & 56 & 35 & 22 & 316 & 181 \\
\hline Species richness & 6 & 6 & 3 & 17 & 14 \\
\hline Table & & 0 & 0 & 0 \\
\hline
\end{tabular}

Table 2. Spatial distribution of anuran species among the six breeding sites, monitored monthly from October 2005 to March 2007 in Morro do Diabo State Park, São Paulo state, southeastern Brazil: permanent dams (PD), permanent streams (PS), and temporary ponds (TP).

PCA analysis showed congruent results with SIMPROF analysis whereas the twodimensional solution of PCA accounted for $61.4 \%$ of the total explained variance (Fig. 3). Third and fourth axes account for few of the total explained variance (only $8.6 \%$ and $6 \%$, respectively). PCA 1 (42.3\%) showed a tendency to segregate among samples of streams (mainly related to Hypsiboas albopunctatus), and samples of permanent dams and temporary ponds (mainly related to Dendropsophus nanus, Hypsiboas raniceps, Leptodactylus podicipinus, Physalaemus cuvieri, and Scinax fuscomarginatus). On the other hand, PCA 2 (19.1\%) showed a tendency to segregate among samples of permanent dams (mainly related to Dendropsophus nanus and Scinax fuscomarginatus) and samples of temporary ponds (mainly related to Chiasmocleis albopunctata, Elachistocleis bicolor, Leptodactylus chaquensis, L. mystacinus, L. podicipinus, Physalaemus cuvieri, Scinax similis, and Trachycephalus typhonius). 

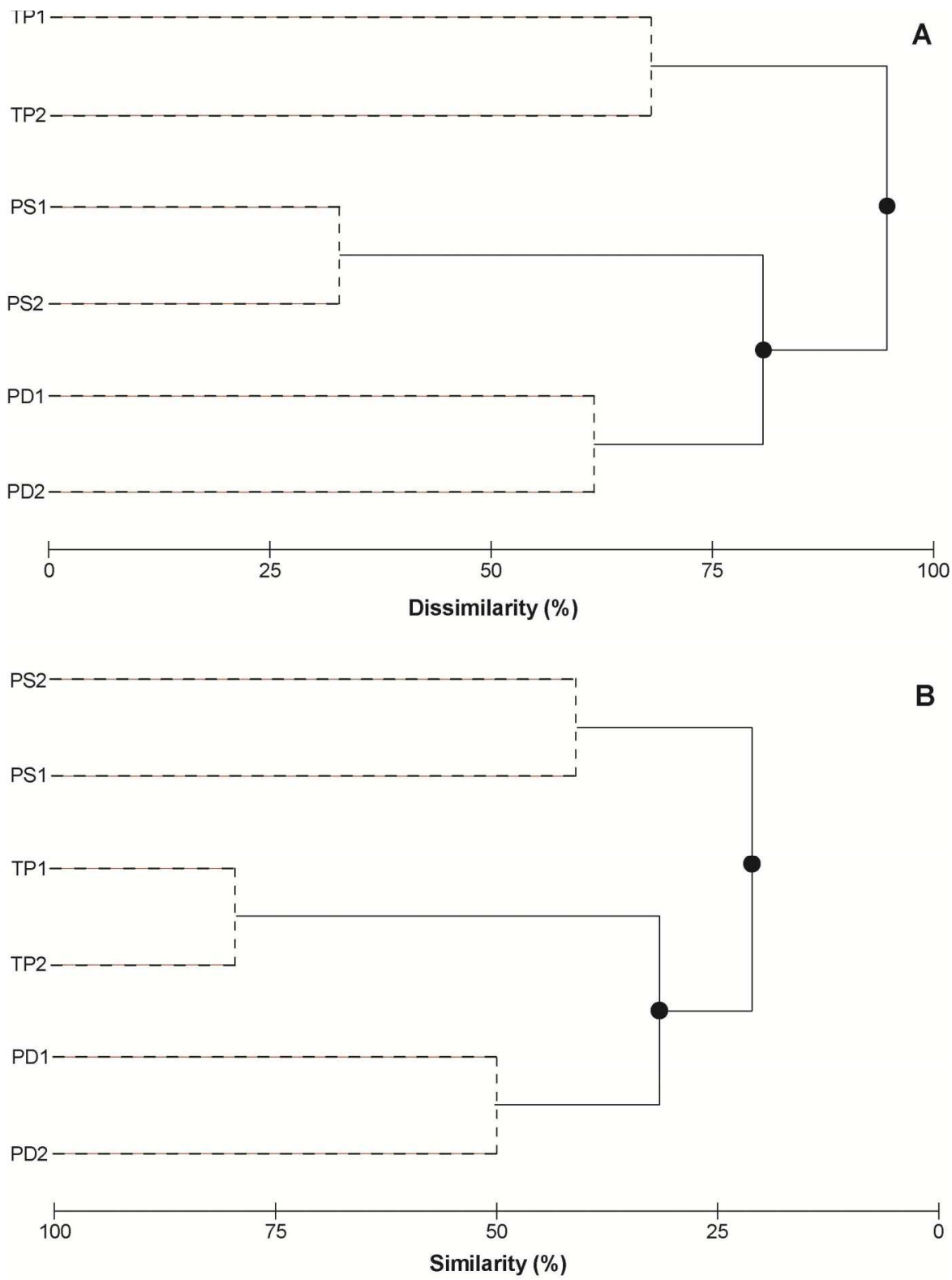

Fig. 2. SIMPROF similarity profile test for environmental characteristics (Euclidian Distance index) (A) and anuran species composition (Bray-Curtis index) (B) recorded in the six breeding sites, monitored monthly from October 2005 to March 2007 in Morro do Diabo State Park, São Paulo state, southeastern Brazil: permanent dams (PD), permanent streams (PS), and temporary ponds (TP). Continuous lines indicate statistically consistent groups $(\mathrm{P}<0.05)$, whereas dotted lines indicate no statistical evidence for any structural pattern $(\mathrm{P}>0.05)$. 


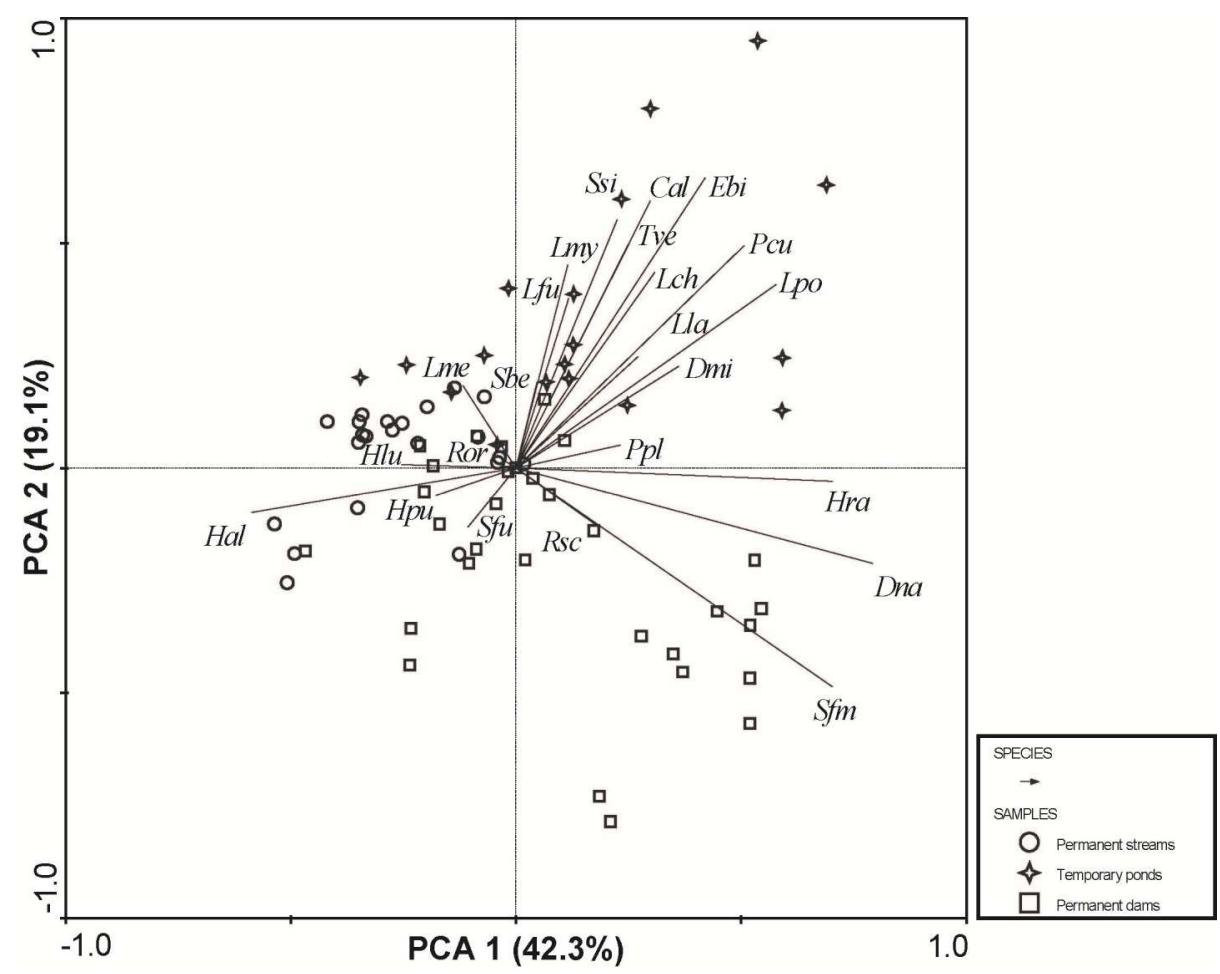

Fig. 3. PCA ordination for 23 anuran species recorded in the six breeding sites, monitored monthly from October 2005 to March 2007 in Morro do Diabo State Park, São Paulo state, southeastern Brazil. Species: Chiasmocleis albopunctata (Cal), Dendropsophus minutus (Dmi), D. nanus (Dna), Elachistocleis bicolor (Ebi), Hypsiboas albopunctatus (Hal), H. lundii (Hlu), H. punctatus (Hpu), H. raniceps (Hra), Leptodactylus chaquensis (Lch), L. fuscus (Lfu), L. labyrinthicus (Lla), L. mystaceus (Lme), L. mystacinus (Lmy), L. podicipinus (Lpo), Physalaemus cuvieri (Pcu), Pseudis platensis (Ppl), Rhinella ornata (Ror), R. schneideri (Rsc), Scinax berthae (Sbe), S. fuscomarginatus (Sfm), S. fuscovarius (Sfu), S. similis (Ssi), and Trachycephalus typhonius (Tve).

Congruent to the results recorded above, ISA results showed that the frequency of occurrence and abundance of 19 anuran species (about $83 \%$ of the total species) is not random when we adopted permanent dams, permanent streams, and temporary ponds as a priori groups in analysis (Table 3, Fig. 4):

Hypsiboas albopunctatus, $H$. lundii, and Rhinella ornata were indicator species of permanent streams.

Dendropsophus nanus, Hypsiboas punctatus, Scinax fuscomarginatus, and S. fuscovarius indicated permanent dams.

Chiasmocleis albopunctata, Dendropsophus minutus, Elachistocleis bicolor, Hypsiboas raniceps, Leptodactylus chaquensis, L. fuscus, L. mystacinus, L. podicipinus, Physalaemus cuvieri, Scinax berthae, S. similis, and Trachycephalus typhonius indicated temporary ponds. 
Four anuran species were not indicators of environmental heterogeneity: Leptodactylus labyrinthicus, L. mystaceus, Pseudis platensis, and Rhinella schneideri (Table 3).

\begin{tabular}{|c|c|c|c|}
\hline Species & Group & IV & $\mathrm{P}$ \\
\hline Chiasmocleis albopunctata & 3 & 27.8 & 0.00 \\
\hline Dendropsophus minutus & 3 & 27.8 & 0.00 \\
\hline Dendropsophus nanus & 2 & 36.2 & 0.03 \\
\hline Elaschistocleis bicolor & 3 & 44.4 & 0.00 \\
\hline Hypsiboas albopunctatus & 1 & 52.9 & 0.00 \\
\hline Hypsiboas lundii & 1 & 13.6 & 0.04 \\
\hline Hypsiboas punctatus & 2 & 21.9 & 0.01 \\
\hline Hypsiboas raniceps & 3 & 33.9 & 0.01 \\
\hline Leptodactylus chaquensis & 3 & 16.7 & 0.02 \\
\hline Leptodactylus fuscus & 3 & 16.7 & 0.02 \\
\hline Leptodactylus labyrinthicus & 3 & 5.6 & ns \\
\hline Leptodactylus mystaceus & 1 & 11.3 & ns \\
\hline Leptodactylus mystacinus & 3 & 38.9 & 0.00 \\
\hline Leptodactylus podicipinus & 3 & 65.1 & 0.00 \\
\hline Physalaemus cuvieri & 3 & 53.2 & 0.00 \\
\hline Pseudis platensis & 3 & 5.6 & ns \\
\hline Rhinella ornata & 1 & 13.6 & 0.04 \\
\hline Rhinella schneideri & 2 & 3.1 & ns \\
\hline Scinax berthae & 3 & 22 & 0.02 \\
\hline Scinax fuscomarginatus & 2 & 38.7 & 0.00 \\
\hline Scinax fuscovarius & 2 & 18 & 0.02 \\
\hline Scinax similis & 3 & 27.8 & 0.00 \\
\hline Trachycephalus typhonius & 3 & 21.2 & 0.01 \\
\hline
\end{tabular}

Table 3. Species Indicator Analysis (ISA) for spatial distribution of anuran species in the six breeding sites, monitored monthly from October 2005 to March 2007 in Morro do Diabo State Park, São Paulo state, southeastern Brazil. Groups: 1) permanent streams; 2) permanent dams; and 3) temporary ponds. Indicator values (IV) and statistical significance $(\mathrm{P})$. $\mathrm{ns}=\mathrm{P}>0.05$. 
The Role of Environmental Heterogeneity in Maintenance

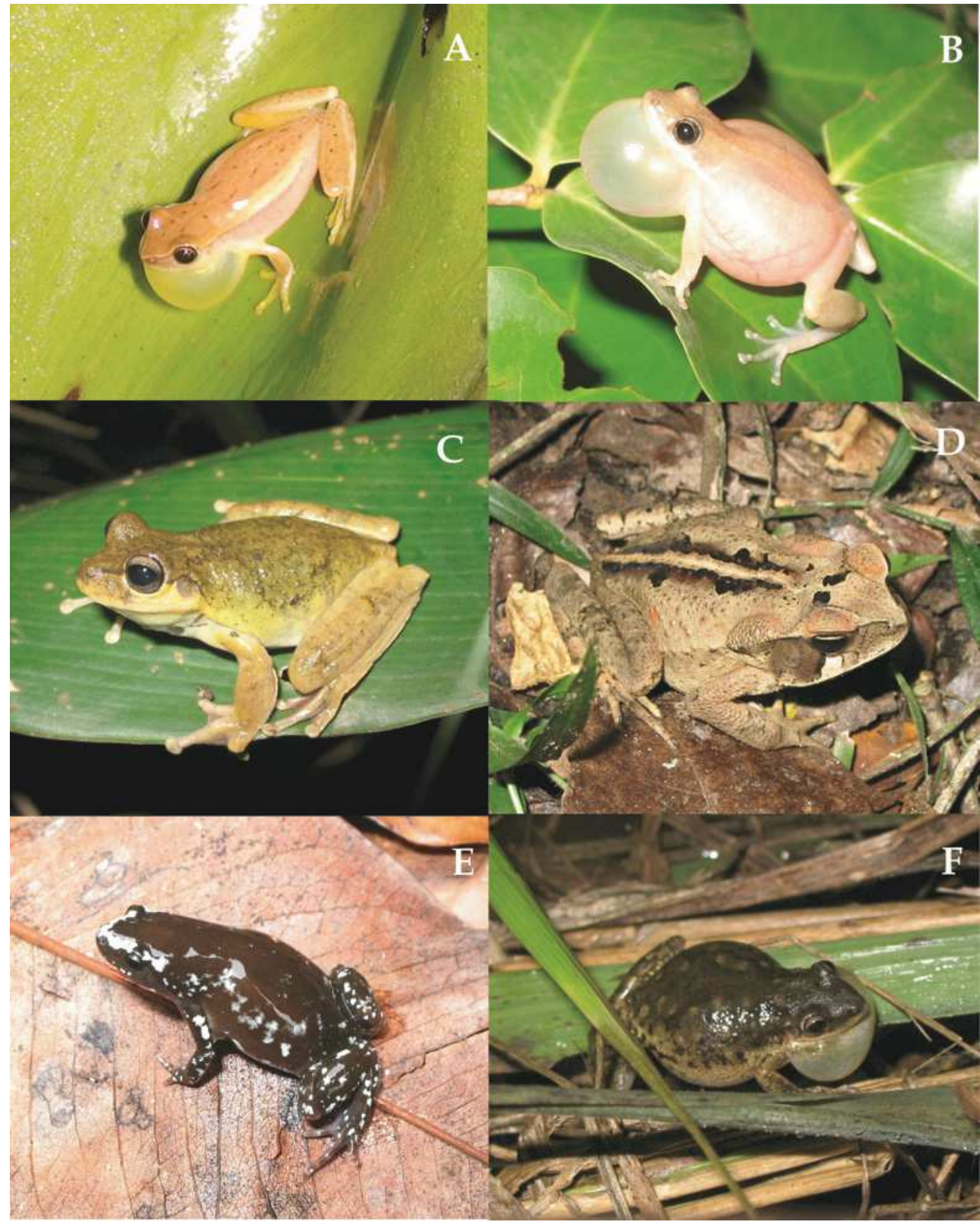

Fig. 4. Some anuran species indicators of environmental heterogeneity at Morro do Diabo State Park, São Paulo State, Brazil: Dendropsophus nanus (A) and Scinax fuscomarginatus (B), typical of permanent dams; Hypsiboas lundii (C) and Rhinella ornata (D), recorded only in permanent streams; and Chiasmocleis albopunctata (E) and Scinax similis (F), typical of temporary ponds. 


\section{Discussion}

Our results indicated that anuran assemblages of MDSP were structured and related to the environmental heterogeneity of breeding sites, disagreeing with Hubbell's neutral model of communities (Hubbell, 2001). Werner et al. (2007) also reported that amphibian assemblages of wetlands in Michigan USA, deviated from the neutral model because spatial distribution of species across breeding sites differed from an expected random distribution, and that assemblage structure was also related to the environmental heterogeneity of ponds (i.e. mainly related to gradients of disturbance, productivity, and pond area). In fact, several studies around the world have shown that adult anurans can actively choose breeding sites according to habitat characteristics (Collins \& Wilbur, 1979; Eason \& Fauth, 2001; Bosch \& Martínez-Solano, 2003; Werner et al., 2007).

We expected a spatial structure of the anuran assemblages, since the groups of monitored breeding sites in MDSP (permanent dams, permanent streams, and temporary ponds) differed widely in relation to environmental characteristics. For Neotropical anuran assemblages, studies have also pointed out differential utilization of breeding sites by adults and/or larvae of anurans (Basso, 1990; Hero, 1990; Eterovick \& Sazima, 2000; Bertoluci \& Rodrigues, 2002; Both et al., 2010; Vasconcelos et al., 2011), although few had effectively used statistical approaches for confirming spatial structure. In the present study, the remarkable degree of concordance between anuran assemblage and environmental plots (i.e. both groups with very similar topology) indicated that the suite of environmental variables has explained spatial patterns of anuran distribution among breeding sites (sensu Clarke \& Gorley, 2006).

We recorded by SIMPROF and PCA analyses, a primary segregation of stream anuran assemblages in MDSP. In fact, few anuran species $(n=7)$ occurred in permanent streams (PS1 and PS2) and all of those occurred only in backwaters, except Rhinella ornata which was also recorded in riffles and running waters. The low anuran species richness recorded in streams was also reported in other localities of southern and southeastern Brazil (e.g. Bernarde \& Anjos, 1999; Bernarde \& Machado, 2001; Brasileiro et al., 2005), which may result from four non exclusive hypotheses: i) phylogenetic constraints related to the historic process of colonization in South America (Zimmerman \& Simberlof, 1996); ii) pressure of aquatic predators (mainly fish) considered strong in this type of environment (e.g. Gascon, 1991; Magnusson \& Hero, 1991); iii) runoff spawns; and iv) morphological limitations in the larval phase (Gascon, 1991). The anuran segregation of streams from the remaining breeding sites (permanent and temporary lentic habitats) differed from the pattern observed in the environmental context, where the external group was composed by temporary ponds, and streams were closely related to the dams. High structural similarity between streams and dams was naturally expected, since dams are originated from dammed streams. However, for anuran assemblages, temporary ponds and dams are more closely related, since both of them are lentic waters, while streams are lotic environments usually unsuitable to colonization.

We recorded through ISA analysis three anuran species as stream indicators: Hypsiboas albopunctatus, H. lundii, and Rhinella ornata. H. albopunctatus occurred in backwaters of streams, very similar to swamps (i.e. in wide stream sections with a mud bed, slow-flowing water, and under natural clearings). According to Cei (1980), H. albopunctatus lives in open 
spaces of forests at the edges of standing waters. However, in most studies this species has been reported as being associated with streams (Haddad et al., 1988; Kwet et al., 2002) and swamps (Brasileiro et al., 2005; Santos et al., 2007) with little water flow. H. albopunctatus has a generalized reproductive mode (mode 1; Haddad \& Prado, 2005) and can be found in human settlements and in disturbed environments (Vasconcelos \& Rossa-Feres, 2005; Santos et al., 2007).

Hypsiboas lundii is an anuran species typical from the Brazilian Cerrado (Frost, 2011), totally dependent on gallery forests (Brasileiro et al., 2005). Reproduction of this species is associated with permanent streams of primary and secondary forests (International Union for Conservation of Nature, 2011). Males usually construct basins in banks of streams where eggs are deposited and tadpoles are carried from the basins after flooding caused by heavy rains (mode 4; Haddad \& Prado, 2005, Eterovick \& Sazima, 2004).

Rhinella ornata is distributed within the Atlantic forest (Frost, 2011). It is a toad that deposits eggs in streams, with exotrophic tadpoles developing in stream backwaters (mode 2; Haddad \& Prado, 2005). Our observations indicate that males of this species call in still backwaters and running waters of MDSP streams, highlighting that this toad species is dependent on forest habitats. In fact, a recent study has demonstrated that populations of $R$. ornata undergo genetic erosion due to habitat fragmentation of the Atlantic Coastal Forest (Dixo et al., 2009).

In the current study, we recorded segregation between assemblages of permanent dams and temporary ponds in MDSP. Anuran species richness in permanent dams (PD1 and PD2) was intermediate in relation to permanent streams and temporary ponds (i.e. higher than permanent streams but lower than temporary ponds). In fact, dams have intermediate features between lotic and lentic environments and these are harmful to the reproduction of many species due to changes in physical and chemical features of the water (Esteves, 1998). These statements were corroborated by Both et al. (2008), since they recorded low diversity and high species dominance in the dam environment monitored in southern Brazil. In the present study, dams were dominated by two anuran species (Dendropsophus nanus and Scinax fuscomarginatus) that have wide distribution in South American biomes and are typically well adapted to anthropogenic disturbances (Duellman, 1999; Frost, 2011; IUCN, 2011). These anuran species have the generalized reproductive mode (mode 1 ; Haddad \& Prado, 2005).

In addition to Dendropsophus nanus and Scinax fuscomarginatus, two other anuran species were indicators of dams: Hypsiboas punctatus and Scinax fuscovarius. The former has a wide distribution comprising South and Central America (Duellman, 1999; Vasconcelos et al., 2006), whilst $S$. fuscovarius present more southern distribution in South America (Frost, 2011). Both species have the generalized reproductive mode (mode 1; Haddad \& Prado, 2005) and occur in either preserved or disturbed areas (Santos et al., 2007, 2008).

On the other hand, we recorded that temporary ponds (TP1 and TP2) supported high anuran species richness and were spatially structured, disagreeing with the stochastic pattern expected for habitats with low predictability (such as temporary water bodies) (Bonner et al., 1997). The pattern of high anuran species richness that we recorded in temporary ponds can be explained by the high productivity usually reported in temporary environments (Williams \& Feltmate, 1992; Brönmark \& Hansson, 2005; Williams, 2006), as 
well as the absence or low abundance of aquatic predators (fish and insects respectively) in comparison with permanent ponds (Heyer et al., 1975; Smith, 1983; Woodward, 1983; Skelly, 1997), and the intermediate-disturbance hypothesis (see Both et al., 2009 for review).

In fact, comparisons of community composition between permanent and temporary waterbodies reveal relatively little overlap regarding the biota (review in Williams, 2006). High species richness has been reported in previous studies on Neotropical anuran assemblages of temporary ponds (e.g. Basso, 1990; Zimmerman \& Simberlof, 1996; Santos et al., 2007; Both et al., 2009) and seems to be related to specific features of these environments that make the colonization by several exclusive anuran species advantageous, mainly by those which are more opportunistic. In the present study, we reported many anuran species as indicators of temporary ponds, and our ecological data indicate that most of them (e.g., Chiasmocleis albopunctata, Elachistocleis bicolor, Leptodactylus chaquensis, Physalaemus cuvieri, Scinax similis, and Trachycephalus typhonius) are opportunistic breeders with calling males starting activity after heavy rains (Santos et al., unpubl. data).

Amphibians that use different types of ponds along the permanence gradient tend to have different life-history characteristics (Semlitsch et al., 1996), such as adaptations to deal with drying ponds. Therefore, anuran species that lay eggs in foam nests (e.g. leiuperids and leptodactylids) have an advantage to explore temporary environments due to protection by the foam against desiccation of eggs and/or embryos (Heyer, 1969; Downie, 1988), and probably against wide fluctuations in water levels, typical of temporary breeding sites (Vasconcelos \& Rossa-Feres, 2005; Santos et al., 2007). In addition, anuran species with a generalized reproductive mode have high reproductive investments (large clutches), faster larval development, and can also show an evolutive response to explore unpredictable environments such as temporary ponds (Basso, 1990). In our study, $42 \%$ of anuran species that were considered as indicators of temporary ponds deposited eggs in foam nests (mode 11: Physalaemus cuvieri and Leptodactylus chaquensis, mode 13: L. podicipinus, and mode 30: L. fuscus and L. mystacinus), while the remaining 58\% presented the generalized reproductive mode (mode 1: Chiasmocleis albopunctata, Elachistocleis bicolor, Dendropsophus minutus, Hypsiboas raniceps, Scinax berthae, S. similis, and Trachycephalus typhonius), highlighting that life-history characteristics of these species allow them to explore temporary sites.

The abundance and frequency of occurrence of four anuran species recorded in MDSP did not differ from the randomly expected distribution (Leptodactylus labyrinthicus, L. mystaceus, Pseudis platensis, and Rhinella schneideri), and consequently did not indicate association with any breeding site. Three of these were rare at the monitored water bodies (Leptodactylus labyrinthicus, Pseudis platensis, and Rhinella schneideri), which makes interpretations on spatial pattern distribution of these species unfeasible. On the other hand, Leptodactylus mystaceus was a ubiquitous anuran species in MDSP. We recorded males of this species calling within mud basins of stream banks and in temporary ponds, as previously reported by Toledo et al. (2003). Reproduction of L. mystaceus takes place in sites seasonally flooded by heavy rains (Duellman, 1978) and tadpoles are able to generate foam, probably as an adaptation to survive in places with unpredictable rainfall (Caldwell \& Lopez, 1989). Therefore, we believe that the reproductive requirements of L. mystaceus seem to be more related to short hydroperiods of breeding sites (such as seasonally flooded banks of permanent streams in MDSP), than to other environmental characteristics, such as lentic or lotic waters. 


\section{Conclusion}

We recorded that anuran assemblages in MDSP were not a random set of species since they were structured according to distinct groups of breeding sites (permanent dams, permanent streams, and temporary ponds). In addition, we also pointed out the existence of species indicators of environmental heterogeneity, i.e. anuran species typical of each group of breeding sites. Regarding indicator species analysis (ISA), we observed lower ISA values associated with anuran indicators of temporary ponds than for those of permanent dams and streams. This result seems to be related to the reproductive patterns of anuran species, since ISA is based on relative abundance and relative frequency of species in the samples (Dufrêne \& Legendre, 1997). Therefore, explosive breeding species that occupied temporary ponds for short periods contributed for few samples (i.e. low frequency of occurrence) in ISA analysis, decreasing the final indicator values. On the other hand, anuran species typical of permanent sites remained in streams and dams for longer periods, increasing indicator values. Despite this possible bias in indicator values, we believed in the robustness of ISA results since we recorded a higher number of anuran species as indicators of temporary ponds than of permanent dams and streams. Ecological consistence of ISA can also be supported by other studies showing the same association of anuran species here indicated by ISA with temporary ponds or permanent breeding sites (Brasileiro et al., 2005; Prado et al., 2005; Santos et al., 2007), although direct comparisons are limited due to the lack of similar statistical approaches.

Our results are relevant to conservation proposals since Mesophytic Semideciduous Forests are the most fragmented and threatened ecosystem of the Atlantic Domain and only $2 \%$ of this forest type remains in the state of São Paulo as "islands of biodiversity" in an agricultural landscape (Viana \& Tabanez, 1996). Therefore, strategies of biodiversity conservation are urgently required for this forest type, and our results have significant implications for anuran conservation actions in remnants of Mesophytic Semideciduous Forest because the importance of heterogeneous breeding sites in the maintenance of high diversity in assemblages of anurans was highlighted. Therefore, the choice of areas for anuran conservation in this forest type must consider the presence of distinct breeding sites such as lotic and lentic environments, as well as sites with different hydroperiods. In this context, the Brazilian Forest Act revision, which hopes to expand agricultural frontiers by clear-cutting the vegetation in riparian zones and legal reserves of private lands, is a recent threat to anuran conservation (Silva et al., 2011). This law proposal, which was approved in the Brazilian Chamber of Deputies, will endanger the water quality and availability, modifying also the hydroperiod of waterbodies used to anuran breeding activity. Besides, the reduction and fragmentation of native vegetation can disconnect areas of shelters and/or foraging from their breeding sites (Becker et al., 2007), as well as promote genetic erosion of anuran species (Dixo et al., 2009).

\section{Acknowledgement}

This study received financial support from the BIOTA/FAPESP program - The Biodiversity Virtual Institute (www.biota.org.br). We thank Capes and $\mathrm{CNPq}$ for the PhD fellowships given to TGS and TSV, respectively. We also thank the Morro do Diabo State Park (MDSP) direction and staff for the logistic support and stimulus and everyone who participated in the fieldwork. We are grateful to Fernando R. Carvalho and Luis G. Gorgatto for fish 
identification, Luciane Ayres Peres for crustacean identification and Marcia Spies for insect identification and Primer-E use. CFBH thanks FAPESP and CNPq for financial support. All sampling in this study has been conducted with applicable state and federal laws of Brazil (IBAMA permit number 02001.007052/2001).

\section{References}

Afonso L.G. \& Eterovick, P.C. (2007). Microhabitat choice and differential use by anurans in forest streams in southeastern Brazil. Journal of Natural History, Vol.41, No.13-16, pp. 937-948, ISSN 0022-2933

Basso, N.G. (1990). Estrategias adaptativas en una comunidad subtropical de anuros. Cuadernos de Herpetología, Serie Monografías, Vol.1, pp. 3-70, ISSN 0326-551X

Becker, C.G.; Fonseca, C.R.; Haddad, C.F.B.; Batista, R.F. \& Prado, P.I. (2007). Habitat split and the global decline of amphibians. Science, Vol.318, pp. 1775-1777, ISSN 1095-9203

Bernarde, P. S. \& Anjos, L. (1999). Distribuição espacial e temporal da anurofauna no Parque Estadual Mata dos Godoy, Londrina, Paraná, Brasil (Amphibia: Anura). Comunicações do Museu de Ciências da PUCRS, Série Zoologia, Vol.12, pp. 127-140, ISSN 0104-6950

Bernarde, P.S. \& Machado, R.A. (2001). Riqueza de espécies, ambientes de reprodução e temporada de vocalização da anurofauna em Três Barras do Paraná, Brasil (Amphibia: Anura). Cuadernos de Herpetología, Vol.14, pp. 93-104, ISSN 0326-551X

Bertoluci, J. \& Rodrigues, M.T. (2002). Utilização de hábitats reprodutivos e micro-hábitats de vocalização em uma taxocenose de anuros (AMPHIBIA) da Mata Atlântica do Sudeste do Brasil. Papéis Avulsos de Zoologia, Vol.42, pp. 287-297, ISSN 0031-1049

Bonner, L.; Diehl, W. \& Altig, R. (1997). Physical, chemical and biological dynamics of five temporary dystrophic forest pools in central Mississippi. Hydrobiologia, Vol.353, pp. 77-89, ISSN 0018-8158

Bosch, J. \& Martínez-Solano, I. (2003). Factors influencing occupancy of breeding ponds in a montane amphibian assemblage. Journal of Herpetology, Vol.37, pp. 410-413 ISSN 0022-1511

Both, C.; Kaefer, I.L.; Santos, T.G. \& Cechin, S.Z. (2008). An austral anuran assemblage in the Neotropics: seasonal occurrence correlated with photoperiod. Journal of Natural History, Vol.42, pp. 205-222, ISSN 0022-2933

Both, C.; Solé, M.; Santos, T.G. \& Cechin, S.Z. (2009). The role of spatial and temporal descriptors for Neotropical tadpole communities in southern Brazil. Hydrobiologia, Vol.124, pp. 125-138, ISSN 0018-8158

Both, C.; Cechin, S.Z.; Melo, A.S. \& Hartz, S.M. (2010). What controls tadpole richness and guild composition in ponds in subtropical grasslands? Austral Ecology, Vol.36, pp. 530-536, ISSN 1442-9985

Brasileiro, C.A.; Sawaya, R.J.; Kiefer, M.C. \& Martins, M. (2005). Amphibians of an open cerrado fragment in southeastern Brazil. In: Biota Neotropica, Vol. 5, 12.07.2011, Available from

http://www.biotaneotropica.org.br/v5n2/pt/abstract?article+BN00405022005 ISSN 1676-0603

Brönmark, C. \& Hansson, L.A. (2005). Biology of Habitats: The Biology of Ponds and Lakes. Oxford University Press, ISBN 01985-16134, NY

Caldwell, J.P. \& Lopez, P.T. (1989). Foam-generating behavior on tadpoles of Leptodactylus mystaceus. Copeia, Vol.1989, pp. 498-502, ISSN 0045-8511 
Cei, J.M. (1980). Amphibians of Argentina. Monitore Zoologico Italiano, Monografie, Vol.2, pp. $1-609$

Chase J.M. \& Leibold, M.A. (2003). Ecological Niches: Linking Classical and Contemporary Approaches. University Chicago Press, ISBN 02261-01800, Chicago

Chase, J.M. (2007). Drought mediates the importance of stochastic community assembly. Proceedings of National Academy of Sciences of the United States of America, Vol.104, pp. 17430-17434, ISSN 0027-8424

Clarke, K.R. \& Gorley, R.N. (2006). Software PRIMER v6. PRIMER-E, Plymouth UK.

Clarke, K.R. \& Warwick, R.M. (2001). Changes in Marine Communities: An Approach to Statistical Analysis and Interpretation. PRIMER-E, Plymouth, UK

Collins, J.P. \& Wilbur, H. (1979). Breeding habits and habitats of the amphibians of the Edwin S. George Reserve, Michigan, with notes on the local distribution of fishes. Occasional Papers of the Museum of Zoology University of Michigan, Vol.686, pp. 1-34, ISSN 0076-8413

Crump, M.L. (1971). Quantitative analysis of the ecological distribution of a tropical herpetofauna. Occasional Papers of the Museum of Natural History, Vol.3, pp. 1-62, ISSN 0091-7958

Dean, W. (1998). A ferro e fogo: a história e a devastação da Mata Atlântica brasileira (1st ed). Companhia das Letras, ISBN 9788571645905, São Paulo, Brazil

Dixo, M.; Metzger, J.; Morgante, J. \& Zamudio, K. (2009). Habitat fragmentation reduces genetic diversity and connectivity among toad populations in the Brazilian Atlantic Coastal Forest. Biological Conservation, Vol.142, pp. 1560-1569, ISSN 0006-3207

Downie, J.R. (1988). Functions of the foam in the foam-nesting leptodactylid Physalaemus pustulosus. Herpetological Journal, Vol.1, pp. 302-307, ISSN 0022-1511

Duellman, W.E. (1978). The biology of an equatorial herpetofauna in Amazon Ecuador. Miscellaneous Publication, University of Kansas, Museum of Natural History, Vol.65, pp. 1-352, ISSN 0075-5036

Duellman, W.E. (1999). Distribution Patterns of Amphibians in the South America, In: Patterns of Distribution of Amphibians: A Global Perspective, W.E. Duellman (ed.), pp. 255-327, Johns Hopkins University Press, ISBN 08018-61152, Maryland

Dufrêne, M. \& Legendre. P. (1997). Species assemblages and indicator species: the need for a flexible asymmetrical approach. Ecological Monographs, Vol.67, pp. 345-366, ISSN 0012-9615

Durigan, G. \& Franco, G.A.D.C. (2006). Vegetação, In: Parque Estadual do Morro do Diabo: Plano de Manejo, H.H. Faria (org.), pp. 111-118, Editora Viena, ISBN 85371-00536, São Paulo, Brazil

Eason Jr., G.W. \& Fauth, J.E. (2001). Ecological correlates of anuran species richness in temporary pools: a field study in South Carolina, USA. Israel Journal of Zoology, Vol.47, pp. 347-365, ISSN 0021-2210

Esteves, F.A. (1998). Fundamentos de Limnologia. Interciência, ISBN 85719-30082, Rio de Janeiro, Brazil

Eterovick, P.C. \& Sazima, I. (2000). Structure of an anuran community in a montane meadow in southeastern Brazil: effects of seasonality, habitat, and predation. Amphibia-Reptilia, Vol.21, pp. 439-461, ISSN 0173-5373

Eterovick, P.C. \& Sazima, I. (2004). Anfíbios da Serra do Cipó, Minas Gerais, Brasil. Editora PUC Minas, ISBN 85864-80355, Minas Gerais, Brazil

Eterovick P.C. \& Barros, I.S. (2003). Niche occupancy in south-eastern Brazilian tadpole communities in montane meadow streams. Journal of Tropical Ecology, Vol.19, pp. 439-448, ISSN 0266-4674 
Faria, A.J. (2006). Clima, In: Parque Estadual do Morro do Diabo: Plano de Manejo, H.H. Faria (org.), pp. 90-96, Editora Viena, ISBN 85371-00536, São Paulo, Brazil

França, F.G.R. \& Araújo, A.F.B. (2007). Are there co-occurrence patterns that structure snake communities in central Brazil? Brazilian Journal of Biology, Vol.67, pp. 33-40, ISSN 1519-6984

Frost, D.R. (2011). Amphibian Species of the World: an Online Reference, Version 5.5. American Museum of Natural History, New York, 12.07.2011, Available from http://research.amnh.org/herpetology/amphibia/

Gascon, C. (1991). Population and community: level analysis of species occurrences of central Amazonian rain forest tadpoles. Ecology, Vol.72, pp. 1731-1746, ISSN 00129658

Gottsberger, B. \& Gruber, E. (2004). Temporal partitioning of reproductive activity in a Neotropical anuran community. Journal of Tropical Ecology, Vol.20, pp. 271-280, ISSN 0266-4674

Haddad, C.F.B.; Andrade, G.V. \& Cardoso, A.J. (1988). Anfíbios anuros do Parque Nacional da Serra da Canastra, estado de Minas Gerais. Brasil Florestal, Vol.64, pp. 9-20, ISSN 0104-4389

Haddad, C.F.B. \& Prado, C.P.A. (2005). Reproductive modes in frogs and their unexpected diversity in the Atlantic Forest of Brazil. Bioscience, Vol.55, pp. 207-217, ISSN 1516-3725

Hero, J.M. (1990). An illustrated key to aquatic tadpoles occurring in the Central Amazon rainforest, Manaus, Amazonas, Brasil. Amazoniana, Vol.11, pp. 201-62, ISSN 0065-6755

Heyer, W.R. (1969). The adaptive ecology of the species groups of the genus Leptodactylus (Amphibia, Leptodactylidae). Evolution, Vol.23, pp. 421-428, ISSN 1558-5646

Heyer, W.R.; McDiarmid, R.W. \& Weigmann, D.L. (1975). Tadpoles, predation and pond habitats in the tropics. Biotropica, Vol.7, pp. 100-111, ISSN 0006-3606

Heyer; M.A. Donnelly; R.W. McDiarmid; L.A.C. Hayek \& M.S. Foster (eds.) (1994). Measuring and Monitoring Biological Diversity: Standard Methods for Amphibians. Smithsonian Institution Press, ISBN 15609-82845, Washington

Hubbell, S.P. (2001). The Unified Neutral Theory of Biodiversity and Biogeography. Monographs in Population Biology. Princeton University Press, ISBN 06910-21287, New Jersey

IUCN, Red List of Threatened Species. 2011. Version 2011.1. Electronic database, 12.07.2011, Available from http://www.iucnredlist.org

Jansen, D.H. (1997). Florestas tropicais secas, In: Biodiversidade, E.O. Wilson (Ed.), pp. 166176, Editora Nova Fronteira, ISBN 85209-0792X, Rio de Janeiro

Krebs, C.J. (1999). Ecological Methodology. Addison Wesley Educational Publishers, ISBN 03210-21738, California

Kwet, A.; Solé, M.; Miranda, T.; Melchiors, J.; Naya, D.E. \& Maneyro, R. (2002). First record of Hyla albopunctata Spix, 1824 (Anura: Hylidae) in Uruguay, with comments on the advertisement call. Boletín de la Asociación Herpetológica Española, Vol.13, pp. 1-2, ISSN 1130-6939

Legendre, P. \& Legendre, L. (1998). Numerical Ecology. Elsevier Scientific Publishing Company, ISBN 04448-92494, Amsterdam, The Netherlands

Leite, J.F. (1998). A Ocupação do Pontal do Paranapanema. Hucitec, ISBN 85271-04601, São Paulo, Brazil

Magnusson, W.E. \& Hero, J.M. (1991). Predation and the evolution of complex oviposition behaviour in Amazon rainforest frogs. Oecologia, Vol.86, pp. 310-318, ISSN 0029-8549

Manly, B.J.F. (1998). Randomization, Bootstrap and Monte Carlo Methods in Biology. University of Otago, Chapman \& Hall, ISBN 04127-21309, New Zealand 
Manly, B.J.F. (2008). Métodos Estatísticos Multivariados: Uma Introdução. Bookman, ISBN 9788577801855, Rio Grande do Sul, Brazil

McCune, B. \& Mefford, M.J. (1999). PC-ORD Multivariate Analysis of Ecological Data, version 4.2. MjM Software Design, Oregon

Murphy, P.G. \& Lugo, A.E. (1986). Ecology of tropical dry forest. Annual Review of Ecology and Systematics, Vol.17, pp. 67-88, ISSN 0066-4162

Paton, P.W.C. \& Crouch, W.B. (2002). Using the phenology of pond-breeding amphibians to develop conservation strategies. Conservation Biology, Vol.16, pp. 194-204, ISSN 0888-8892

Pennington, R.T.; Ratter, J.A. \& Lewis, G.P. (2006). An overview of the plant diversity, biogeography and conservation of Neotropical savannas and seasonally dry forests, In: Neotropical savannas and seasonally dry forests: plant diversity, biogeography and conservation, R.T. Pennington, G.P. Lewis \& J.A. Ratter (eds), pp. 1-29, CRC Press, ISBN 0849329876, Boca Raton

Prado, D.E. (2000). Seasonally dry forests of tropical South America: from forgotten ecosystems to a new phytogeographic unit. Edinburgh Journal of Botanic, Vol.57, No.3, pp. 437-461, ISSN 0960-4286

Prado, D.E. \& Gibbs, P.E. (1993). Patterns of species distributions in the dry seasonal forests of South America. Annals of the Missouri Botanical Garden, Vol.80, pp. 902-927, ISSN 0026-6493

Prado, C.P.A.; Uetanabaro, M. \& Haddad, C.F.B. (2005). Breeding activity patterns, reproductive modes, and habitat use by anurans (Amphibia) in a seasonal environment in the Pantanal, Brasil. Amphibia-Reptilia, Vol.26, pp. 211-221, ISSN 0173-5373

Santos, T.G.; Rossa-Feres, D.C. \& Casatti, L. (2007). Diversidade e distribuição espaçotemporal de anuros em região com pronunciada estação seca no Sudeste do Brasil. Iheringia, Série Zoologia, Vol.97, pp. 37-49, ISSN 0073-4721

Santos, T.G.; Kopp, K.; Spies, M.R.;Trevisan, R. \& Cechin, S.Z. (2008). Distribuição temporal e espacial de anuros em área de Campos Sulinos (Santa Maria, RS). Iheringia, Série Zoologia, Vol.98, pp. 244-253, ISSN 0073-4721

Santos, T.G.; Vasconcelos, T.S.; Rossa-Feres, D.C. \& Haddad, C.F.B. (2009). Anurans of a seasonally dry tropical forest: Morro do Diabo State Park, São Paulo state, Brazil. Journal of Natural History, Vol.43, pp. 973-993, ISSN 0022-2933

Scott Jr., N.J. \& Woodward, B.D. (1994). Surveys at breeding sites, In: Measuring and Monitoring Biological Diversity: Standard Methods for Amphibians, W.R. Heyer; M.A. Donnelly; R.W. McDiarmid; L.A.C. Hayek \& M.S. Foster (eds.), pp. 84-92, Smithsonian Institution Press, ISBN 15609-82845, Washington

Semlitsch, R.D.; Scott, D.E.; Pechmann, J.H.K. \& Gibbons, J.W. (1996). Structure and dynamics of an amphibian community: evidence from a 16-year study of a natural pond, In: Long-Term Studies of Vertebrate Communities, M.L. Cody \& J. Smallwood (eds.), pp. 217-248, Academic Press, ISBN 01217-80759, California

Silva, F.R.; Prado, V.H.M. \& Rossa-Feres, D. de C. (2011). Value of Small Forest Fragments to Amphibians. Science, Vol.332, pp. 1033, ISSN 1095-9203

Skelly, D.K. (1997). Tadpole communities. American Scientist, Vol.85, pp. 36-45, ISSN 00030996

Smith, D.C. (1983). Factors controlling tadpole populations of the chorus frog (Pseudacris triseriata) on Isle Royale, Michigan. Ecology, Vol.64, pp. 501-510, ISSN 0012-9658 
Snodgrass, J.W.; Komoroski, M.J.; Bryan, A.L. \& Burger, J. (2000). Relationships among isolated wetland size, hydroperiod, and amphibian species richness: implications for wetland regulations. Conservation Biology, Vol.14, pp. 414-419, ISSN 0888-8892

ter Braak, C.J.F. \& Smilauer, P. (1998). CANOCO Reference Manual and User's Guide to Canoco for Windows: Software for Canonical Community Ordination, version 4. Microcomputer Power, New York

Tilman, D. (2004). Niche tradeoffs, neutrality, and community structure: a stochastic theory of resource competition, invasion, and community assembly. Proceedings of National Academy of Sciences of the United States of America, Vol.101, pp. 10854-10861, ISSN 0027-8424

Toft, C.A. (1982). Community structure of letter anurans in a tropical forest, Makokou, Gabon: a preliminary analysis in the minor dry season. Revue d'Écologie (La Terre de la Vie), Vol.36, pp. 223-232, ISSN 0249-7395

Toft, C.A. (1985). Resource partitioning in amphibians and reptiles. Copeia, Vol.1985, pp. 121, ISSN 0045-8511

Toledo, L.F.; Zina, J. \& Haddad, C.F.B. (2003). Distribuição espacial e temporal de uma comunidade de anfíbios anuros do município de Rio Claro, São Paulo, Brasil. Holos Environment, Vol.3, pp. 136-149, ISSN 1519-8634

Vasconcelos, T.S. \& Rossa-Feres, D.C. (2005). Diversidade, distribuição espacial e temporal de anfíbios anuros (Amphibia, Anura) na região Noroeste do estado de São Paulo, Brasil. Biota Neotropica, Vol.5, 12.07.2011, Available from http:/ / www.biotaneotropica.org.br/v5n2/pt/abstract?article+BN01705022005 ISSN 1676-0603

Vasconcelos, T.S.; Santos, T.G. \& Haddad, C.F.B. (2006). Amphibia, Hylidae, Hypsiboas punctatus: Extension and filling distribution gaps. Check List, Vol.2, pp. 61-62, ISSN 1809-127X

Vasconcelos, T.S.; Santos, T.G.; Rossa-Feres, D.C. \& Haddad, C.F.B. (2009). Influence of the environmental heterogeneity of breeding ponds on anuran assemblages from Southeastern Brazil. Canadian Journal of Zoology, Vol.87, pp. 699-707, ISSN 0008-4301

Vasconcelos, T.S.; Santos, T.G.; Rossa-Feres, D.C. \& Haddad, C.F.B. (2011). Spatial and temporal distribution of tadpole assemblages (Amphibia, Anura) in a seasonal dry tropical forest of southeastern Brazil. Hydrobiologia, Vol.673, pp. 93-104, ISSN 00188158

Viana, V.M. \& Tabanez, A.A.J. (1996). Biology and conservation of forest fragments in the Brazil Atlantic Moist Forest, In: Forest Patches in Tropical Landscapes, R. Schella \& R. Greenberg (eds.), pp. 151-167, Island Press, ISBN 15596-3426X, Washington

Wells, K.D. (2007). The Ecology and Behavior of Amphibians. University of Chicago Press, ISBN 978022-6893341, Illinois

Werner, E.E.; Skelly, D.K.; Relyea, R.A. \& Yurewicz, K. (2007). Amphibian species richness across environmental gradients. Oikos, Vol.116, pp. 1697-1712, ISSN 0030-1299

Williams, D.D. (2006). The Biology of Temporary Waters. Oxford, ISBN 01985-28124, New York

Williams, D.D. \& Feltmate, B.W. (1992). Aquatic Insects. Oxford University Press, ISBN 08519-87826, UK

Woodward, B.D. (1983). Predator-prey interactions and breeding pond use of temporarypond species in a desert anuran community. Ecology, Vol.64, pp. 1549-1555, ISSN 0012-9658

Zimmerman, B.L. \& Simberloff, D. (1996). An historical interpretation of habitat use by frogs in a central Amazonian forest. Journal of Biogeography, Vol.23, pp. 27-46, ISSN 03050270 


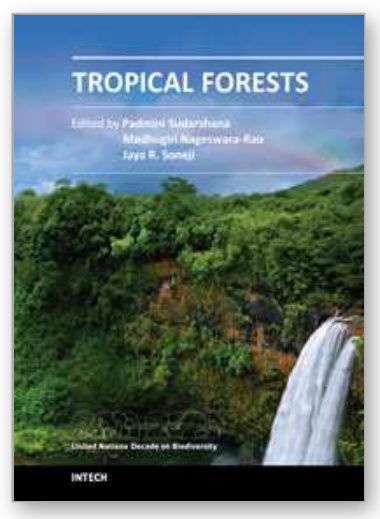

\author{
Tropical Forests \\ Edited by Dr. Padmini Sudarshana
}

ISBN 978-953-51-0255-7

Hard cover, 388 pages

Publisher InTech

Published online 14, March, 2012

Published in print edition March, 2012

The astounding richness and biodiversity of tropical forests is rapidly dwindling. This has severely altered the vital biogeochemical cycles of carbon, phosphorus, nitrogen etc. and has led to the change in global climate and pristine natural ecosystems. In this elegant book, we have defined "Tropical Forests" broadly, into five different themes: (1) tropical forest structure, synergy, synthesis, (2) tropical forest fragmentation, (3) impact of anthropogenic pressure, (4) Geographic Information System and remote sensing, and (5) tropical forest protection and process. The cutting-edge synthesis, detailed current reviews, several original data-rich case studies, recent experiments/experiences from leading scientists across the world are presented as unique chapters. Though, the chapters differ noticeably in the geographic focus, diverse ecosystems, time and approach, they share these five important themes and help in understanding, educating, and creating awareness on the role of "Tropical Forests" for the very survival of mankind, climate change, and the diversity of biota across the globe. This book will be of great use to the students, scientists, ecologists, population and conservation biologists, and forest managers across the globe.

\title{
How to reference
}

In order to correctly reference this scholarly work, feel free to copy and paste the following:

Tiago Gomes dos Santos, Tiago da Silveira Vasconcelos and Célio Fernando Baptista Haddad (2012). The Role of Environmental Heterogeneity in Maintenance of Anuran Amphibian Diversity of the Brazilian Mesophytic Semideciduous Forest, Tropical Forests, Dr. Padmini Sudarshana (Ed.), ISBN: 978-953-51-02557, InTech, Available from: http://www.intechopen.com/books/tropical-forests/the-role-of-environmentalheterogeneity-in-maintenance-of-anuran-amphibian-diversity-of-the-brazilia

\section{INTECH}

open science / open minds

\section{InTech Europe}

University Campus STeP Ri

Slavka Krautzeka 83/A

51000 Rijeka, Croatia

Phone: +385 (51) 770447

Fax: +385 (51) 686166

www.intechopen.com

\section{InTech China}

Unit 405, Office Block, Hotel Equatorial Shanghai

No.65, Yan An Road (West), Shanghai, 200040, China

中国上海市延安西路65号上海国际贵都大饭店办公楼405单元

Phone: +86-21-62489820

Fax: +86-21-62489821 
(C) 2012 The Author(s). Licensee IntechOpen. This is an open access article distributed under the terms of the Creative Commons Attribution 3.0 License, which permits unrestricted use, distribution, and reproduction in any medium, provided the original work is properly cited. 